\title{
The Demand For Community Supported Agriculture
}

\author{
John M. Polimeni, Albany College of Pharmacy \\ Raluca Iorgulescu Polimeni, Siena College \\ Richard L. Shirey, Siena College \\ Christina L.Trees, SUNY-Cobleskill \\ W. Scott Trees, (trees@ siena.edu), Siena College
}

\begin{abstract}
Community Supported Agriculture (CSA) has undergone both a rapid increase in growth and interest over the last decade. As such, the amount of literature on the subject has also increased. However, there are few, if any, theoretical models of demand on CSA that have been developed from membership data. This paper uses both survey and anecdotal data of members of the Roxbury Biodynamic Farm, the second largest CSA in the United States, to present a theory of demand for CSA membership. Included in the discussion is consideration of the evidence that there is a direct relationship between production method and demand, usually a shibboleth in traditional economic analysis. Further exploration considers the possibility that over time participation influences the very nature of demand for CSA membership, and hypothesizes that this dynamic demand is a necessary but insufficient condition for the sustainability of CSA.
\end{abstract}

\section{INTRODUCTION}

Community Supported Agriculture (CSA) has undergone rapid growth during the last decade. This has led to a concurrent increase in the number of articles and books on the subject by, among others, economists, sociologists, and anthropologists on topics such as, how to successfully run and organize a CSA farm (VanEn, 1992; DeLind, 1990), analyzing the aspects of participation in community building (Cone, 2000), the pricing of CSA shares (Cooley and Lass, 1997, 1998), and technology used in CSA production (Lass and Sanneh, 1996). However, little has been written about the nature and complexity of demand for CSA membership. This is not surprising since non-price factors influencing demand cannot be fully understood using the traditional microeconomic analysis that other studies have employed.

Therefore, consumer behavior, as modeled by economists, must be re-evaluated when examining an issue such as CSA. Elster (1989) and Sen $(1976,1977,1979,1982)$ argue, counter to utility theory, that consumers want to satisfice goals. The authors criticize traditional rational choice theory, in particular one preference ordering which is supposed to reflect a person's interests and welfare in order to explain their actual choices and behavior. Other research builds upon these criticisms, taking into account that consumption meets a variety of needs and wants for individuals. Doyal and Gough (1991) reject the claim of neoclassical theory that needs are definable. They find that in order to maximize the satisfaction of basic needs individuals must have the entitlement and the health to work together to have meaningful and democratic negotiations. Max-Neef (1992) examined needs and wants of consumers to develop the concept of satisfiers. He argues that the needs of consumers can be scrutinized objectively, in contrast to the subjective approach of neoclassical economics. Moreover, he finds that consumption can be counterproductive to well-being because at a certain level of standard of living, an improvement in quality-of-life has little, if anything, to do with consumption. Frank (1997) extended previous research by examining the utility function of homo economicus with a conscience, implying that utility may be reference based. His findings are consistent with new research findings on happiness which find that subjective measures of well-being are reasonably constant over time, even with large increases in consumption spending. Paavola (2001) examines individual behavior informed by ethical concerns for the environment as a strategy for obtaining sustainable consumption. He compares models of rational choice under standard individual actor assumptions with models developed to analyze non-selfish and welfare-centered motivations 
of consumer choice. Paavola finds that universally shared nonutilitarian values for the environment makes consumption more sustainable because consumer choices include motivations that are often not related to individual welfare.

Some economists are now using subjective questions to measure well-being, replacing gross domestic product and individual utility (Oswald, 1997; Blanchflower and Oswald, 2004). The objective of this research is to understand what makes people happy and to link this to individual behavior. Making this connection is important to evaluate the impact of policies that result in trade-offs between income and variables such as environmental quality and health. This relationship between the environment and subjective well-being is a relatively new area of research (Rangel, 2003; Welch, 2002). Furthermore, this research on well-being and consumption is pertinent to the mounting interest about the environment and the sustainability of human societies (Diamond, 2005).

Resource allocation by suppliers is determined by consumer decisions about which goods and services to purchase. This relationship, first coined by Hutt (1936) as consumer sovereignty, has become an important term in environmental sustainability research. A sovereign consumer transfers resources from less to more socially valued uses. Individual interests should be strongly discouraged, if not bought out, and freedom of the individual is guaranteed when market operations are performed with impersonality and impartiality (Reekie, 1988). Norton et al. (1998) highlight the stress between social and individual interests when examining consumer sovereignty and sustainability. They find that a command-and-control approach makes people feel deprived of contributing to sustainability, whereas an approach that allows preferences to influence decision-making makes people better-off and proud to contribute to sustainability. Consumers, knowledgeable of altruistic motives, are capable and often willing to make consumption choices which do not improve and may decrease their welfare (Paavola, 2001). The interaction with the farm, farmer, and other members is part of sustaining and deepening consumer demand for CSA because tastes and preferences change as the social institution (the farm) changes.

\section{WHAT IS CSA?}

Community Supported Agriculture, in the broadest sense, is a group of people who share in both the production and consumption of agricultural output. Although many of the characteristics of CSA farms seem similar to those unfamiliar with the concept, it would be misleading to think that these similarities are shared by all CSA farms. For example, larger ventures may have full-time farmers who use available technology, while smaller farms often do not. Most CSA is organic, diverse in the variety of production, and focused on fruits and/or vegetables. However, there are notable exceptions. In this context, even the concept of community does not necessarily mean a geographic location, and sharing in production does not mean that members always provide labor. In short, CSA is a community in the sense that members share common goals and share many of the same experiences in trying to achieve these goals. Members provide financing to the farm by buying shares, typically much in advance of the growing season, which entitles them to a part of the food that is grown. Furthermore, members are expected to contribute a few working hours on the farm or distribution site or pay a small premium to opt out of this requirement. This method of financing is important because members share the risk and uncertainty inherent in agricultural production (Lamb, 1996; Padel and Lampkin, 1994), allowing the farmer to purchase the seeds and other production goods and to have a guaranteed income for the year (Stern, 1992; Karr, 1993).

Consumer demand for shares in Roxbury Farm, a CSA located in rural Columbia County, New York, is the focus of this study. The Roxbury Farm CSA was started in 1990, growing to the second largest CSA in the United States, with approximately 675 members or an estimated 2,000 or more consumers. Members of the Roxbury Farm come from three distinct regions: (1) a third from New York City, (2) a sixth from Columbia County, and (3) half from the Capital District area near Albany, New York. From early June through December, produce is delivered to different distribution sites where members go to pick up their share, typically during a two to four hour period on a designated day. On average, members receive 400 pounds of vegetables per year, all of which are grown on just thirty of the over one hundred forty acres of land on the farm. 


\section{A TRADITIONAL THEORY OF CSA DEMAND}

A traditional microeconomic demand analysis assumes that a CSA farm maximizes profits and has some monopoly power, typically through geographic location. Equation 1.1 provides a traditional microeconomic model for CSA memberships.

$$
Q_{v t}=f\left(P, P_{s}, P_{c}, I, N, T, M, W, E, H\right)=f\left(X_{1}\right)
$$

Where $Q_{v t}=$ quantity demanded for CSA farm memberships

$$
\begin{aligned}
& P=\text { price of a bundle of vegetables from a CSA farm } \\
& P_{s}=\text { price of a substitute bundle of vegetables } \\
& P_{c}=\text { price of complements } \\
& I=\text { income } \\
& N=\text { number of potential consumers } \\
& T=\text { consumer tastes and preferences } \\
& M=\text { marketing } \\
& W=\text { word of mouth } \\
& E=\text { expectations } \\
& H=\text { personal health reasons }
\end{aligned}
$$

The demand for CSA farm memberships is, in essence, a demand for fresh vegetables since vegetables are the primary product grown. The price of vegetables $(P)$ are tangible and quantifiable making comparisons to substitutes $\left(P_{s}\right)$, equivalent bundles from grocery stores, supermarkets, or farmer markets, rather straightforward. Less clear is the price of complements $\left(P_{c}\right)$. Traditionally, $P_{c}$ would include all the costs associated with a CSA membership, such as travel costs to the pick-up site each week and the opportunity cost of lost leisure time caused by the work requirement. These costs are relatively easy to quantify, while other costs, such as the loss of the choice of vegetables or the opportunity costs associated with having to store and prepare food, are difficult to quantify.

The variables $I, N, T, E$, and $H$ are similar to those included in most demand functions found in introductory level microeconomic textbooks. Income $(I)$ reflects the average household income level in the market. A CSA membership is considered a normal good, therefore income is assumed to be positively correlated with $Q_{v t}$. $N$ is the size of the market, measured by the number of potential consumers. $T$ is a set of consumer tastes and preferences, assumed to be a measure of the intensity of a household's desire to buy fresh, locally grown, organic produce. $E$ represents the expectations of members. Members of a CSA farm are not sure about the quantity, quality, or variety of produce they will receive each week. Therefore, if the expectations of members are met or exceeded, demand will increase. However, if expectations are not met, demand will decrease. Furthermore, expectations are different depending upon how long a person has been a member of the CSA. New members will have different expectations than those whom have been members in previous years. $H$ is a set of health benefits that members believe they will receive from fresh vegetables from a CSA. In addition to these traditional variables, a measure of marketing or advertising $(M)$ and word-of-mouth $(W)$ sales, which is harder to quantify, were also added to the demand equation. Assuming independent consumer choice is highly unrealistic, as family members, peers, and neighbors do care about each others' consumption choices (Paavola, 2001), $W$ is a necessary inclusion in any model of demand for CSA membership. 
Although equation 1.1 represents a theoretical model of demand, the equation is rarely the econometric model underpinning empirical research on CSA due to the difficulty and expense of trying to measure many of the variables. Understanding this, Cooley and Lass (1997) developed an abbreviated model, depicted in equation 1.2.

$$
Q_{v t}=f\left(P, P_{s}\right)
$$

Their model examines the relationship between CSA share prices and the prices of substitutes. Their empirical investigation led them to conclude that CSA shares are less expensive than equivalent amounts of both organic and regular produce at retail stores (Cooley and Lass,1997, p. 234).

\section{THE RESEARCH METHOD AND RESULTS}

To better understand the members of Roxbury Farm, their motivations, experiences, and relationship with the farmer and the farm, a survey was conducted to develop an alternative model of demand for CSA. Two hundred fiftyseven out of 675 members filled out the survey at their delivery site, for a response rate of 38\%, extremely high for this type of research. The survey results yielded the following results.

Approximately $86 \%$ of the Roxbury Farm respondents learned about the farm from a friend/family CSA member or from a CSA member. Nearly $71 \%$ of the respondents were female, the majority of which have an education of a Bachelor's degree or higher. Roxbury Farm households tend to be wealthy. Seventy-four percent of respondents have a pre-tax household income of $\$ 40,000$ or more per year. Of this group, $70 \%$ earn $\$ 60,000$ or more. To further stress this point, nearly $31 \%$ of the households responding earn at least $\$ 80,000$ per year. These member characteristics can be seen in Table 1 .

Table 1. Characteristics Of Members At Roxbury Farm Csa.

\begin{tabular}{|c|c|}
\hline \multicolumn{2}{|c|}{ Member Characteristics } \\
\hline \multicolumn{2}{|l|}{ Gender } \\
\hline Male & $29 \%$ \\
\hline Female & $71 \%$ \\
\hline \multicolumn{2}{|c|}{ Pre-tax Household Income } \\
\hline less than $\$ 10,000$ & $1.40 \%$ \\
\hline$\$ 10,000-\$ 19,999$ & $5.45 \%$ \\
\hline$\$ 20,000-\$ 39,999$ & $19.05 \%$ \\
\hline$\$ 40,000-\$ 59,999$ & $22.40 \%$ \\
\hline$\$ 60,000-\$ 79,999$ & $21.10 \%$ \\
\hline$\$ 80,000$ or more & $30.60 \%$ \\
\hline
\end{tabular}

These results may not be surprising, but the reason why members joined Roxbury, as illustrated in Table 2, has some interesting and significant findings. Ninety-nine percent of respondents indicated that receiving fresh vegetables was either very important or important in their decision to join the CSA, while $93 \%$ gave the same responses for wanting to receive organic vegetables. Of nearly equal importance, ninety-one percent stated that support for a local farm was very important or important when deciding whether to join Roxbury Farm or not. Eightynine percent and eighty-two percent indicated that concern for the environment or for their health, respectively, was either very important or important in their membership decision.

Not surprisingly, few members indicated that it was important or very important for them to work on a farm $(15 \%)$ or to learn how to grow vegetables $(16 \%)$. Only $25 \%$ of respondents felt that it was important or very important 
for their children to have access to a farm. Learning about biodynamic agriculture or how vegetables are grown was important or very important to approximately $40 \%$ of the members.

Some of the results proved to be rather surprising. For example, only forty-four percent of respondents indicated that risk sharing with the farmer was important or very important to them. Slightly more, $47 \%$, respondents stated that the price of the vegetables was very important or important in their decision to join the farm. This result is particularly counter to traditional economic theory, illustrating that people joined the Roxbury CSA for reasons other than financial. Lastly, about half of respondents joined the CSA because a sense of community was important to them.

Table 2. Factors Important To Members When They Joined Roxbury Farm Csa (Percentages Rounded To Nearest Whole Number).

\begin{tabular}{|c|c|c|c|c|c|}
\hline & $\begin{array}{c}\text { Very } \\
\text { Important }\end{array}$ & Important & Indifferent & Unimportant & $\begin{array}{c}\text { Very } \\
\text { Unimportant }\end{array}$ \\
\hline Want Fresh Vegetables & $76 \%$ & $23 \%$ & $1 \%$ & $1 \%$ & $0 \%$ \\
\hline Want Organic Vegetables & $65 \%$ & $28 \%$ & $5 \%$ & $2 \%$ & $0 \%$ \\
\hline Want to Support Local Farms & $55 \%$ & $36 \%$ & $9 \%$ & $0 \%$ & $0 \%$ \\
\hline $\begin{array}{l}\text { Want to Eat Vegetables in } \\
\text { Season } \\
\text { Want to Know Where }\end{array}$ & $33 \%$ & $40 \%$ & $24 \%$ & $3 \%$ & $1 \%$ \\
\hline Vegetables Come From & $28 \%$ & $37 \%$ & $22 \%$ & $9 \%$ & $4 \%$ \\
\hline $\begin{array}{l}\text { Concern for the Environment } \\
\text { Want a Stronger Sense of }\end{array}$ & $53 \%$ & $36 \%$ & $11 \%$ & $0 \%$ & $0 \%$ \\
\hline $\begin{array}{c}\text { Community } \\
\text { Want to Know How }\end{array}$ & $11 \%$ & $40 \%$ & $40 \%$ & $8 \%$ & $1 \%$ \\
\hline Vegetables are Grown & $9 \%$ & $31 \%$ & $40 \%$ & $14 \%$ & $6 \%$ \\
\hline $\begin{array}{c}\text { Price of Vegetables } \\
\text { Want to Share Risk With }\end{array}$ & $7 \%$ & $40 \%$ & $39 \%$ & $10 \%$ & $3 \%$ \\
\hline Farmers & $12 \%$ & $32 \%$ & $42 \%$ & $12 \%$ & $2 \%$ \\
\hline Concerned About Health & $40 \%$ & $42 \%$ & $14 \%$ & $3 \%$ & $2 \%$ \\
\hline $\begin{array}{l}\text { Want to Reduce Packaging } \\
\text { Want to Know More About }\end{array}$ & $25 \%$ & $40 \%$ & $26 \%$ & $6 \%$ & $3 \%$ \\
\hline $\begin{array}{c}\text { Biodynamic Agriculture } \\
\text { Want to Know How to Grow }\end{array}$ & $8 \%$ & $31 \%$ & $42 \%$ & $13 \%$ & $6 \%$ \\
\hline $\begin{array}{l}\text { Vegetables } \\
\text { Want to Give Children Access }\end{array}$ & $3 \%$ & $13 \%$ & $50 \%$ & $20 \%$ & $14 \%$ \\
\hline to a Farm & $8 \%$ & $17 \%$ & $38 \%$ & $14 \%$ & $23 \%$ \\
\hline Want to Work on a Farm & $4 \%$ & $11 \%$ & $39 \%$ & $21 \%$ & $25 \%$ \\
\hline
\end{tabular}

While these results by themselves might not seem very important, how member attitudes and perceptions changed after they joined Roxbury Farm, shown in Table 3, is imperative to develop a model of demand for CSA. Interestingly enough, there was an increase in the percentage of members responding either important or very important in all the survey questions except two, which remained the same. Just like their responses to their initial reason for joining the CSA, 99\% of people responded that getting fresh vegetables was either very important or important to them now that they have been a member of Roxbury Farm. However, the number of members responding that fresh vegetables are very important to them now increased 7\%. Member responses about getting organic vegetables were similar, having an increase of $13 \%$ in members stating this was very important to them. Ninety-seven percent of members responded that supporting a local farm was either very important or important to them now that they are a member, an increase of 6\%. Furthermore, the percentage of respondents indicating that supporting a local farm was very important increase by $18 \%$. Ninety-six percent of members now feel that concern for the environment was either important or very important, an increase of $7 \%$. Those responding very important increased by $20 \%$. When asked about how they feel about joining the farm for health reasons, an additional $7 \%$ of members responded it was 
either important or very important to them. Those responding health reasons were very important to them now increased by $10 \%$.

The five questions that were lowest ranked before joining the farm, were still the five lowest ranked questions now, although they all increased in percentage terms. Working on the farm remained the least important reason for having a membership with Roxbury Farm. Only 25\%, an increase of 10\%, responded that working on the farm was either important or very important to them now. Thirty-two percent of members, an increase of $16 \%$, said that knowing how to grow vegetables was important to them now. Taking children to the farm also increased by $16 \%$ in the very important or important categories. Sixty-two percent of members responded that knowing more about biodynamic agriculture was very important or important to them now, an increase of $23 \%$. Lastly, knowing how vegetables are grown increased by $21 \%$ in the important or very important categories.

Table 3. Factors Important To Members Of Roxbury Farm Csa Now (Percentages Rounded To Nearest Whole Number).

\begin{tabular}{|c|c|c|c|c|c|}
\hline & $\begin{array}{c}\text { Very } \\
\text { Important }\end{array}$ & Important & Indifferent & Unimportant & $\begin{array}{c}\text { Very } \\
\text { Unimportant }\end{array}$ \\
\hline Get Fresh Vegetables & $83 \%$ & $16 \%$ & $0 \%$ & $1 \%$ & $0 \%$ \\
\hline Get Organic Vegetables & $78 \%$ & $15 \%$ & $5 \%$ & $1 \%$ & $0 \%$ \\
\hline Support Local Farms & $73 \%$ & $24 \%$ & $4 \%$ & $0 \%$ & $0 \%$ \\
\hline $\begin{array}{l}\text { Eat Vegetables in Season } \\
\text { Know Where Vegetables }\end{array}$ & $53 \%$ & $36 \%$ & $10 \%$ & $1 \%$ & $0 \%$ \\
\hline Come From & $49 \%$ & $29 \%$ & $16 \%$ & $4 \%$ & $2 \%$ \\
\hline Concern for the Environment & $63 \%$ & $33 \%$ & $4 \%$ & $0 \%$ & $0 \%$ \\
\hline $\begin{array}{l}\text { Develop a Stronger Sense of } \\
\text { Community }\end{array}$ & $25 \%$ & $41 \%$ & $28 \%$ & $4 \%$ & $1 \%$ \\
\hline Grown & $21 \%$ & $40 \%$ & $25 \%$ & $9 \%$ & $4 \%$ \\
\hline Price of Vegetables & $13 \%$ & $43 \%$ & $32 \%$ & $9 \%$ & $3 \%$ \\
\hline Share Risk With Farmers & $26 \%$ & $43 \%$ & $26 \%$ & $5 \%$ & $1 \%$ \\
\hline Do Something for My Health & $50 \%$ & $39 \%$ & $10 \%$ & $1 \%$ & $0 \%$ \\
\hline $\begin{array}{l}\text { Reduce Packaging } \\
\text { Know More About }\end{array}$ & $39 \%$ & $41 \%$ & $15 \%$ & $3 \%$ & $1 \%$ \\
\hline $\begin{array}{l}\text { Biodynamic Agriculture } \\
\text { Know How to Grow }\end{array}$ & $16 \%$ & $46 \%$ & $27 \%$ & $8 \%$ & $4 \%$ \\
\hline Vegetables & $8 \%$ & $24 \%$ & $44 \%$ & $14 \%$ & $10 \%$ \\
\hline Take My Children to the Farm & $14 \%$ & $27 \%$ & $27 \%$ & $9 \%$ & $23 \%$ \\
\hline Working on the Farm & $7 \%$ & $18 \%$ & $43 \%$ & $13 \%$ & $19 \%$ \\
\hline
\end{tabular}

\section{AN ALTERNATIVE THEORY OF CSA DEMAND}

Using the data collected through the member surveys, an alternative model of demand for CSA memberships will be developed because understanding the decision-making process of members is vital. Being a member of a CSA farm is not easy, often requiring a lifestyle change. During the growing season, vegetables are relentless and some must be stored for future use, and the diversity of vegetables means that some will be unfamiliar and/or disliked. However, the demand for CSA shares is not simply a demand for vegetables, for if it were, competition from food cooperatives, farmers markets, and even the organic produce section of local supermarkets might decrease the demand for shares at a CSA farm. Additionally six months a year produce cannot be grown and members are forced to purchase vegetables from somewhere other than a CSA farm. Thus, recidivism of members must be incorporated into the demand model. If members do not learn and/or value the changes they undergo by participating in a CSA, demand will weaken over time and members will leave. More formally, if learning does not occur, then the gap between perceived opportunity cost and actual opportunity cost will be relatively large, decreasing the probability that a member will rejoin a CSA farm the following year. 
Lass and Sanneh (1996, p. 1) found that market prices do not reflect actual costs or benefits when external benefits and costs are considered. Building upon their findings, Equation 2.1 offers a model that addresses the complexity and richness of the CSA experience.

$Q_{c s a_{1}}=f\left(X_{1}, B_{1}, G_{1}, S_{1}, R_{1}\right)$

Where $Q_{c s a_{1}}=$ quantity demanded for CSA memberships in the first year

$X_{1}=$ a vector of the exogenous variables included in Equation 1.1

$B_{1}=$ the labor requirement by the CSA (this can be bought out which effectively

raises the price of membership)

$G_{1}=$ environmental awareness

$S_{1}=$ social conscience (support for local farms)

$R_{1}=$ risk shared with farmer

Unique conditions, typically not made explicit in models of demand for CSA memberships, confront the potential first year member. For example, members face the very real risk of crop failure by the farmer, and the dynamic of how to manage a diverse bundle of vegetables every week. Therefore, $Q_{c s a_{1}}$ represents CSA memberships, which includes the right to vegetables grown during the season, as well as other benefits which first year members may or may not be aware of or appreciate. $B_{1}$ is the labor requirement to either work on the farm or participate in some other aspect of the CSA. Members can buy out of this requirement, but by doing so raise the price of membership. Environmental awareness, $G_{1}$, represents the preference for environmental services, and $S_{1}$, uses the support of the farmer/local business as a proxy for social conscience. Finally, $R_{1}$ captures the risk that members share with the farmer. These additional variables were included because some members derive positive utility from feeling that they are, in a sense, partners with the farmer in an uncertain business.

\section{CSA DEMAND: THE SECOND YEAR}

The responses collected in the survey consistently and significantly indicated that members changed their attitudes toward the farm and environmental issues. Therefore, a dynamic model of demand that incorporates learning must be constructed. During the first year of membership, the household will learn from the farmer and other members of the CSA farm. Thus, demand for membership in the second year is driven by how much a member learns from their CSA experience in the first year. The feedback to members during the year and their ability to compare their CSA experience with their conventional market experience leads the member to either discontinue or maintain their membership. Building upon this knowledge, the model of demand for a CSA farm membership in the second year takes on the following functional form.

$Q_{c s a_{2}}=f\left(X_{2}, B_{2}, G_{2}, S_{2}, R_{2}\right)$

Where $Q_{c s a_{2}}=$ quantity demanded for CSA memberships in the second year

$X_{2}=$ a vector of the variables included in Equation 1.1

$B_{2}=$ the labor requirement by the CSA (this can be bought out which effectively

raises the price of membership)

$G_{2}=$ environmental awareness 
$S_{2}=$ social conscience (support for local farms)

$R_{2}=$ risk shared with the farmer

And

$$
X_{2}=f\left(L_{1}\right)
$$

$B_{2}=f\left(L_{1}\right)$

$G_{2}=f\left(L_{1}\right)$

$S_{2}=f\left(L_{1}\right)$

$R_{2}=f\left(L_{1}\right)$

$L_{1}=f\left(V_{1}, C_{1}, Z_{1}\right)$

Where $L_{1}=$ learning that occurred in year 1

$V_{1}=$ time volunteered beyond $B_{1}$

$C_{1}=$ willingness or openness to change

$Z_{1}=$ social learning

Although equation 2.2 looks similar to equation 2.1, they are very different. Using what members learn ( $\left.L_{1}\right)$ in year 1, the values of all the variables in equation 2.2 are endogenously impacted, as illustrated in equation 2.3. For example, price $(P)$ has less importance to CSA farm members in each subsequent year of participation. Furthermore, for many CSA members, the learning that is inherently a part of participation, heightens concern about the use of agricultural chemicals and non-sustainable farm practices, hence the inclusion of the variables $G_{2}, S_{2}$, and $Z_{1}$. An interesting finding is that part of the learning process and openness to change $\left(C_{1}\right)$ comes from a personal relationship with the farmer. Moreover, many CSA farms recognize the importance of learning, and try to facilitate the process by publishing newsletters, where members are taught how to clean, store, and prepare vegetables, as well as provided detailed information on the production processes used in growing and harvesting vegetables. If no learning occurs by the member, then demand for CSA membership will be represented by Equation 2.1. It is worth noting that even if no learning occurs, demand is different from what standard demand theory. However, such a scenario is highly unlikely, thus a theory of demand that incorporates learning must be developed.

\section{TOWARD A GENERALIZED THEORY OF CSA DEMAND}

Using the logic and demand equations outlined above, a generalized theory of demand for CSA membership is expressed in equation 2.4.

$$
Q_{c s a_{t}}=f\left(X_{t}, B_{t}, G_{t}, S_{t}\right)
$$

Where $Q_{c s a_{t}}=$ quantity demanded for CSA memberships in year $\mathrm{t}$

$X_{t}=$ a vector of the variables included in Equation 1.1

$B_{t}=$ the labor requirement by the CSA (this can be bought out which effectively

raises the price of membership)

$G_{t}=$ environmental awareness 
$S_{t}=$ social conscience (support for local farms)

$R_{t}=$ risk shared with the farmer

$$
\text { And } \quad \begin{aligned}
X_{t} & =f\left(L_{t-1}\right) \\
& B_{t}=f\left(L_{t-1}\right) \\
G_{t} & =f\left(L_{t-1}\right) \\
S_{t} & =f\left(L_{t-1}\right) \\
R_{t} & =f\left(L_{t-1}\right)
\end{aligned}
$$

Where $L_{t-1}=\sum L_{1}, L_{2}, L_{3} \ldots L_{t-1}$. Similar to equation 2.2 , all the covariates in equation 2.4 are endogenously affected by all the learning that occurred as a member in years 1 through $\mathrm{t}-1$. Of particular importance is that members will have different demand functions based on their years of participation. Therefore, the total demand function for CSA memberships, at a particular moment in time, takes the following form:

$$
Q_{c s a}=\sum Q_{c s a_{1}}, Q_{c s a_{2}}, \ldots, Q_{c s a_{t}}
$$

\section{DISCUSSION AND IMPLICATIONS}

Other research on CSA demand has taken a more traditional microeconomic approach, focusing on market prices and member characteristics. Hinrichs (2000) computed per unit prices for the vegetables received by CSA members and then compared these values to the prices that might be paid if the vegetables were purchased in venues such as supermarkets, cooperatives, and organic food stores. She finds that a CSA share is an economic transaction inundated in trust (p. 200). Other studies have shown that, on average, CSA members pay less for their produce than what is paid by those who purchase similar vegetables at all other outlets except for supermarkets. However, the cost difference at supermarkets is very small and the vegetables are not organic, not locally grown, and not fresh (Cooley and Lass, 1998). Unfortunately, by limiting their analysis to a demand for vegetables instead of the complete CSA experience, other studies are simplistic because they ignore the complexity and dynamic nature of CSA and have proven to be useful only for first year members. Other research emphasizes the relationship with the farmer, in particular the risk sharing, while noting that sustaining member trust and participation is more than a market relationship (Guenthner, 1996).

Others have criticized this approach, showing that the share price relative to the quantity and variety of vegetables received does not take into account the explicit and implicit costs, which if included would skew the findings against participation in CSA farms. The most obvious explicit cost is transportation to and from the pick-up site. Implicit costs, many of which were discussed above, include travel time costs to the pick-up site and opportunity costs for the work requirement. Using a traditional economic approach, joining a CSA would be irrational unless the price was better than a more convenient supplier.

Critics of a non-traditional economic approach have either missed or chosen to ignore the implicit and explicit costs associated with the purchase of food in non-CSA situations, particularly travel to and from supermarkets. In addition, consumers often have to endure congestion, lines, and the impersonal nature of modern grocery shopping. Information about the food in supermarkets can be misleading, and worries about freshness and pesticide residue are common.

Studies by these critics often ignore the social costs of traditional agricultural consumption. Often, there is significant waste of food because stores have to stock vegetables which may not be in demand, causing excess use of pesticides and inorganic fertilizers. This excess supply of vegetables can lead to a significant waste of packaging material and energy use in traditional retail stores. Also, consumers have become accustomed to having fruits and 
vegetables out of season from imports, which increases transportation costs. The increased purchase of imported produce has encouraged producers to commit resources, such as preservatives, to improve shelf-life. All of these externalities result in major costs to the environment.

When all of these costs are taken into consideration, the scale is heavily weighted against purchasing vegetables in more traditional settings. If one does an analysis with all the costs and benefits, then the benefits strongly outweigh the costs of joining a CSA. Furthermore, unless one lives in a very small community where shopping is a form of socializing, frequenting large retail outlets provides little benefits other than the value of the goods purchased. For a CSA farm like Roxbury, being a member means more than just receiving vegetables. Therefore, it is important to ask if the demand for CSA represents a case of traditional demand and if it does not, to ask what factors contribute to its uniqueness. In this paper, a model of CSA demand was presented that illustrates the dynamics of household behavior that is not possible through traditional microeconomic analysis. The model offered more accurately describes the embedded learning, as described by the survey data, that impacts the intertemporal demand of CSA membership.

\section{REFERENCES}

1. Blanchflower, D. G. and A. J. Oswald, Well-Being Over Time in Britain and the USA, Journal of Public Economics (88), 2004, 1359 - 1386.

2. Cone, C. A. and A. Myhre, Community-Supported Agriculture: A Sustainable Alternative to Industrial Agriculture, Human Organization (59), 1988, 187 - 202.

3. Cooley, J. and D. Lass, What's Your Share Worth? Some Comparisons of CSA Share Cost Versus Retail Produce Value, 1997 CSA Farm Network, Northeast Organic Farming Association.

4. -------- Consumer Benefits from Community Supported Agriculture Membership, Review of Agricultural Economics (20) 1998, 227 - 237.

5. DeLind, L. B., Close Encounters With a CSA: The Reflections of a Bruised and Somewhat Wiser Anthropologist, Agriculture and Human Values (16), 1990, 3 - 9.

6. Diamond, J., Collapse: How Societies Choose to Fail or Succeed, Viking Press, New York, 2002,

7. Doyal, L. and I. Gough, A Theory of Human Need, Guildford Press, New York, 1991.

8. Elster, J., Solomonic Judgments: Studies in the Limitations of Rationality, Cambridge University Press, Cambridge, 1989.

9. $\quad$ Frank, R. H., The Frame of Reference as a Public Good, Economic Journal (107) 1997, 1832 - 1847.

10. Guenther, D., Community Supported Agriculture: Niche Market or Paradigm Shift, In: Greenbook '96. Saint Paul: Minnesota Department of Agriculture, 1996.

11. Hinrichs, C. C., Embeddedness and Local Food Systems, Journal of Rural Studies (16), 2002, 295 - 303.

12. Hutt, W. H., Economists and the Public, Jonathan Cape, London, 1936.

13. Karr, P., The Last Best Hope for Family Farms, Sanctuary, Journal of the Massachusetts Audubon Society (32), 1993, 5-9.

14. Lamb, G., Community Supported Agriculture: Can It Become the Basis for a New Associative Economy? In: S. Gilman (ed.) 1996 CSA Farm Network, Stillwater, NY: Northeast Organic Farming Association, 1996.

15. Lass, D. and N. Sanneh, Costs and Returns for CSA Operations in the Northeast: Preliminary Results from the 1996 Survey, 1996. http://www.umass.edu/resec/fac+staff/csa1.html.

16. Max-Neef, M. A., Development and Human Needs, In: P. Ekins and M. A. Max-Neef (eds.) 1992, Real-Life Economics: Understanding Wealth Creation, Routledge, London, 1992.

17. Norton, B., R. Costanza, and R. Bishop, The Evolution of Preferences: Why Sovereign Preferences May Not Lead to Sustainable Policies and What to do About It, Ecological Economics (24), 1998, 193 - 211.

18. Oswald, A. J., Happiness and Economic Performance, Economic Journal (107), 1815 - 1831.

19. Paavola, J., Towards Sustainable Consumption: Economics and Ethical Concerns for the Environment in Consumer Choices, Review of Social Economy (LIX), 2001, 227 - 248.

20. Padel, S. and N. H. Lampkin, Farm-level Performance of Organic Farming Systems: An Overview, In: N. H. Lampkin and S. Padel (eds.), The Economics of Organic Farming: An International Perspective. Wallingford: CAB International, 1994. 
21. Rangel, A., Forward and Backward Generational Goods: Why is Social Security Good for the Environment? American Economics Review (93), 2003, 813 - 824.

22. Reekie, W. D., Consumers Sovereignty Revisited, Managerial and Decision Economics (9), 460 - 470.

23. Sen, A. K., Poverty an Ordinal Approach to Measurement, Econometrica (44), 1976, 373 - 387.

24. ------- Rational Fools: A Critique of the Behavioral Foundations of Economic Theory, Philosophy and Public Affairs (6), 1977, 1979, 317 - 344; reprinted in H. Harris, ed., Scientific Models and Man: The Herbert Spencer Lectures 1976, Oxford: Clarendon Press.

25. $\quad$----- Choice, Welfare, and Measurement, Blackwell Publishers, Oxford, 1982.

26. Stern, P., Subscription Squash, and Celery, and Spinach, etc., In Context: A Quarterly of Humane Sustainable Culture (31), 1992, 8.

27. Van En, R., Basic Formula to Create Community Supported Agriculture, Great Barrington, MA., 1992.

28. Welsch, H., Preferences Over Prosperity and Pollution: Environmental Valuation Based on Happiness Surveys", Kyklos (55), 2002, 473 - 494. 
NOTES 